\title{
THE CRISIS OF 1803-1805 IN THE TWO CASTILES: FOODSTUFF, MORTALITY AND INSTITUTIONAL COLLAPSE*
}

\author{
ENRIQUE LLOPIS \\ Universidad Complutense $^{\mathrm{a}}$ \\ FELIPA SÁNCHEZ \\ Universidad Complutense ${ }^{\mathrm{a}}$
}

To Gonzalo Anes and Ángel García Sanz.

in memoriam

\begin{abstract}
The essential aims of this article are: (1) to measure the magnitude of the crisis of 1803-1805 in the two Castiles; (2) to analyse the causes and consequences of this crisis. Among the main conclusions of this essay we would like to underline: (a) the 1803-1805 crisis led to a fall in the population of Castile of about 15 per cent; (b) the severe rise in the price of grains in those years was due to the bad harvests and the sparse working capacity of the municipal grain stores, but more than anything else it was the collapse of the market for this produce as a result of the prohibition of removing grain; (c) government measures to deal with the crisis were numerous and relatively bold, but not very effective; (d) the strong mobilisation of the people disrupted the working of some of the basic institutions of the Ancien Régime.

* Received 1 February 2015. Accepted 3 June 2015. This work has been funded with money from Research Projects, HAR2009-12436 from the Ministerio de Ciencia e Innovación, and HAR2012-33810 from the Ministerio de Economía y Competitividad.

a Departamento de Historia e Instituciones Económicas II; Universidad Complutense; Campus de Somosaguas; 28223, Pozuelo de Alarcón (Madrid). llopisagelan@ccee.ucm.es, fsanchez@ ccee.ucm.es
\end{abstract}


Keywords: crisis, castile, 1803-1805, shortage, popular disturbances

JEL Code: N34, N43, N53, P42

\section{RESUMEN}

Los objetivos esenciales de este artículo son: 1) medir la magnitud de la crisis de 1803-1805 en las dos Castillas; 2) analizar las causas y consecuencias de dicho desastre productivo y demográfico. Entre las principales conclusiones de este ensayo, quisiéramos subrayar: a) la crisis de 1803-1805 provocó una merma en la población castellana de cerca de un 15\%; b) el brutal encarecimiento de los granos en dichos años obedeció a las malas cosechas y a la escasa capacidad operativa de los pósitos, pero sobre todo al colapso del mercado de dichos productos fruto de la prohibición de la saca de cereales; c) las medidas gubernamentales frente a la crisis fueron numerosas y relativamente atrevidas, pero muy poco eficaces; d) la fuerte movilización popular desestabilizó el funcionamiento de algunas instituciones básicas del Antiguo Régimen.

Palabras clave: crisis, castilla, 1803-1805, escasez, revueltas populares

\section{INTRODUCTION}

This essay deals with one of the greatest crises in essential foodstuff and epidemics ever known in Ancien Régime Spain: that of 1803-1805. In European rural communities, in general, the death rate was significantly more sensitive to food price rises than it was in China or Japan where a 10 per cent price increase only led to a 1-2 per cent rise in the death rate. In European countries, however, higher prices increased the possibilities of dying by 7-8 per cent (Campbell et al. 2004, p. 70). Some Asian states, particularly the Chinese, made great efforts to ensure that the whole population had access to a minimum level of food in times of shortage (Lee et al. 2004, p. 86). In contrast, Spain found itself in a part of Eurasia where a high cost of living led to relatively important demographic disasters.

In some Western European countries, lack of essential food and/or death rate crises began to ease in the second half of the $17^{\text {th }}$ century ${ }^{1}$; in Spain, this was not the case until a century later, at least in the interior of the peninsula, and, moreover, crises in cereal crops and epidemics recurred with uncommon force between 1802 and 1814 (Abarca et al. 2015). In the early $19^{\text {th }}$ century, no

\footnotetext{
${ }^{1}$ On the case of Italy, see Del Panta and Livi Bacci (1977, pp. 411-424).
} 
other European country registered a demographic crisis like that suffered in a large area of the Spanish territory in 1803-1805 (Chesnais 1986, pp. 500-503).

Why should we give special significance to the demographic and agrarian crises of 1803-1805? In the area of Castile, since the plague of 1596-1602, there had been no mortality crisis comparable to that of the first years of the $1800 \mathrm{~s}$ (Pérez Moreda 1980, pp. 376, 390). The 1803-1805 crisis was particularly widespread and highly intensive in all the Castilian provinces and such a crisis was not outstanding merely for its size. Its singular nature had its roots in several phenomena. In the first place, popular reaction to the price increases and the acute food shortage was more extended and much more profound than on previous occasions. Movements by broad sectors of the population handicapped the bringing out of the grain, which seriously affected the performance of the corresponding markets. What is more, there was fraud in the payment of tithes, something unknown hitherto ${ }^{2}$. And, second the reaction of the monarchy to the high prices, hunger and epidemics could be described as relatively rapid, intensive, innovative and bold. The active part taken by the authorities to tackle the serious nature of the problems produced by the lack of food and the high sickness and death rates responded to the fact that they saw a great risk that if they did nothing there would be serious disruptions of public order. Furthermore, there was a more entrenched idea that public authorities should intervene more actively in matters of public welfare ${ }^{3}$.

Leading on from this introduction, the article has the following structure: in section 2 there is an analysis of how the Castilian economy evolved in the period before the 1803-1805 crisis. In the third section, this development is measured via the evolution of prices and of deaths and baptisms. The fourth section presents the measures taken by governments to reduce unemployment, high prices, hunger and mortality, as well as a description of how the public and municipal authorities dealt with the difficulties and orders from the monarch; and, finally, in the last section some conclusions are presented.

\section{THE DECADE OF 1790}

In the Spanish interior the crisis in the early years of the $19^{\text {th }}$ century was preceded by a period of significant demographic and agrarian growth.

${ }^{2}$ In several villages of the archbishopric of Toledo, among others in Carranque, agricultural producers, claiming poor harvests and other pretexts, were refusing to pay the tithe in those years ( «Expediente formado ... a consulta del Consejo un oficio del M. R. Cardenal Arzobispo de Toledo ... en que manifiesta los perjuicios que sufren ... como quantos tienen algún derecho a los Diezmos por las defraudaciones y abusos advertidos con bastante generalidad en los pueblos de dicha Diócesis en el modo de diezmar», Archivo Histórico Nacional (henceforth AHN), Consejos, file 3323, record 29, fols. 2-v-3. See also Rodríguez López-Brea (1995, pp. 285-294).

3 The «enlightened» economic-political program, largely followed by the monarchy, involved a fresh definition of and an increase in functions taken on by the state in order to boost economic development and improve the population's level of welfare (Llombart 2000, pp. 76-81). 
Between the 1780s and the 1790s the index of baptisms, as can be seen in Table 1, showed an 8.1 per cent increase in the two Castiles and a rise of 8.4 per cent in the interior of Spain. In the areas away from the coast, throughout the second half of the $17^{\text {th }}$ century, the greatest increases in the number of baptisms were seen in the 1750s and the 1790s.

The population increase in the final decade of the $18^{\text {th }}$ century was especially strong in areas where the number of inhabitants was small and there was plenty of space for increased crop cultivation. Aragon, Castile-La Mancha and western Andalusia (in the latter territory, the index of baptisms rose by 15.1 per cent) were such cases. In the interior areas, the turnof-the-century growth was driven by need (the increasing number of mouths to be fed was the result of a growth in the number of births and a moderate death rate $^{4}$ ), as well as by greater incentives deriving from a notable increase in cereal prices, in absolute and relative terms. There were also opportunities to obtain higher yields from ploughing up fields thanks to the fact that it became easier to commit fraud on tithe payments and, finally, resistance from landowning rentiers, large stockbreeders, and the associations of sheep owners (La Mesta) to the extension of crops diminished (Llopis 2014) ${ }^{5}$.

Figure 1 shows the strong upward trend in the price of wheat in the Spanish interior from the mid 1780s: in Segovia and Medina de Rioseco the annual price quoted for this cereal increased, between 1760/1761-1784/1785 and $1785 / 1786-1799 / 1800$, by 46.2 per cent and 51.4 per cent, respectively. Moreover, price differentials with the periphery grew considerably at the end of the $18^{\text {th }}$ century. This was because the post-revolutionary and Napoleonic wars made imports of grain from ports more irregular and expensive ${ }^{6}$ : on average, the price of wheat in Barcelona was 39.5 per cent and 71.8 per cent higher than in Segovia in 1760/1761-1791/1792 and in 1792/1793-1800/1801, respectively. This in turn raised incentives for the interior to produce more cereals to supply the periphery.

The significant growth in the 1790s leads us to believe that the crisis of the early $19^{\text {th }}$ century was a phenomenon of a relatively exogenous nature to Castilian society and its economy. Nevertheless, the disasters in the 3 years between 1803 and 1805 were not unrelated to the growing number of problems in previous years: (1) the high inflation in the last years of the $18^{\text {th }}$ century and the early 1800 s had harmed the economy seriously in the case of families depending essentially on money from wages ${ }^{7}$; $(2)$ albeit to a

\footnotetext{
4 For the evolution of the death rate in the $18^{\text {th }}$ century, see Abarca et al. (2015).

5 Many years have passed since Antonio Miguel Bernal drew our attention to the magnitude of the breakups in Andalusia in the latter part of the $18^{\text {th }}$ century (Bernal 1979, pp. 172-173). On the rise in demand for land to plough up in the 1790s, see Sánchez Salazar (1988, p. 66).

${ }^{6}$ On the rising price of imports on a world scale in the last part of the $18^{\text {th }}$ century and the first 15 years of the $19^{\text {th }}$ century, see O'Rourke (2006, pp. 123-149).

7 In Palencia, for example, the average wage of daily-paid workers showed a 19.3 per cent fall from 1778-1787 to 1788-1799 (Moreno Lázaro 2002, p. 111).
} 
TABLE 1

REGIONAL AND SUPRAREGIONAL INDICES OF BAPTISMS, 1740-1809 (BASE 100 = AVERAGE FOR 1700-1749)

\begin{tabular}{|l|c|c|c|c|c|c|c|c|}
\hline Decade & La Rioja & Aragon & $\begin{array}{c}\text { Castile and } \\
\text { Leon }\end{array}$ & Madrid & $\begin{array}{c}\text { Castile-La } \\
\text { Mancha }\end{array}$ & Extremadura & $\begin{array}{c}\text { Both } \\
\text { Castiles }\end{array}$ & Inner Spain \\
\hline $1740-1749$ & 100.0 & 100.0 & 100.0 & 100.0 & 100.0 & 100.0 & 100.0 & 100.0 \\
\hline $1750-1759$ & 106.1 & 109.7 & 109.0 & 107.6 & 106.7 & 109.2 & 108.1 & 108.4 \\
\hline $1760-1769$ & 106.0 & 127.2 & 114.5 & 108.9 & 113.0 & 109.8 & 113.4 & 115.1 \\
\hline $1770-1779$ & 101.9 & 124.5 & 113.4 & 103.3 & 113.4 & 114.3 & 112.4 & 114.3 \\
\hline $1780-1789$ & 107.5 & 123.3 & 120.2 & 105.4 & 115.5 & 119.0 & 117.2 & 118.1 \\
\hline $1790-1799$ & 116.0 & 136.5 & 127.4 & 119.7 & 127.5 & 126.9 & 126.7 & 128.0 \\
\hline $1800-1809$ & 112.4 & 133.2 & 111.9 & 107.2 & 108.8 & 123.8 & 110.5 & 115.8 \\
\hline
\end{tabular}

Source: Llopis (2014, pp. 393-394). 
FIGURE 1

WHEAT PRICES IN SEGOVIA AND MEDINA DE RIOSECO, 1760/1761-1808/1809 (IN REALES/FANEGA). MOBILE 9-YEAR AVERAGES

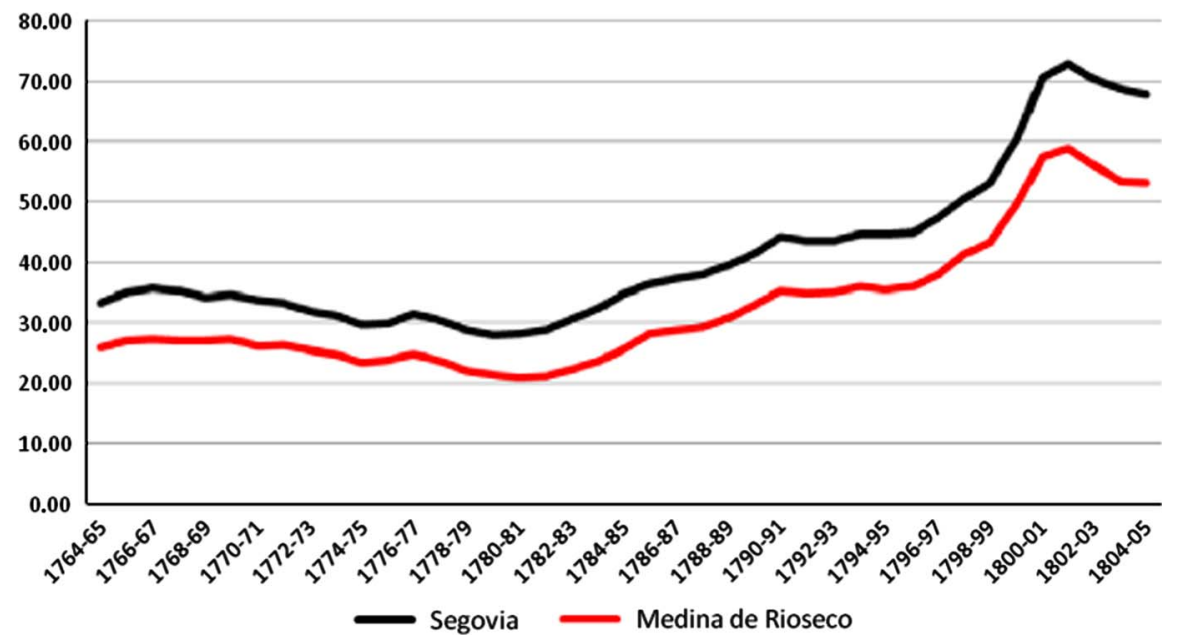

Source: Llopis and Sotoca (2005a).

lesser extent than in coastal areas, inland areas were affected directly or indirectly by the slump and greater irregularity of international trade (Prados de la Escosura 1993, pp. 253-329); (3) the extraordinary 300-million real subsidy established in the decree of 6 November 1799 involved an additional fiscal burden of great significance at a time when the economic situation in many towns of Castile had already worsened ${ }^{8}$; and (4) the exhaustion of the agricultural impulse and substandard harvests in the years immediately before 1803 led to food supply problems even before the crisis came ${ }^{9}$. Consequently, endogenous factors played an important role in the disasters of 1803-1805.

\section{THE EXTENT OF THE 1803-1805 CRISIS: PRICES, MORTALITY AND NATALITY}

The 1803-1805 crisis was of a mixed character: the demographic setbacks were the outcome of very high food prices and important epidemics

8 The case of Segovia in García Sanz (1977, pp. 418-425).

9 On the uprisings for basic food in various places in Ciudad Real and Toledo in 1802, see Fernández Hidalgo and García Rupérez (1989, p. 345). 
occurring in the area of Castile. We will look first at the rise in the price of wheat and its causes.

In Table 2 and Figure 2 we have reflected the path of the average yearly and monthly prices of wheat in several Castilian markets between 1799/1800 and 1805/1806 and between July 1802, and December 1805, respectively.

The spectacular rise in prices began in 1800/1801. Prices rose faster in Castile and Leon than in Castile-La Mancha. Between 1799/1800 and $1800 / 1801$ the price of wheat in all markets listed in Table 2 increased by a mean of 35.4 per cent. The upward movement remained at a fairly high level in 1801/1802: between this agricultural year and the previous one, wheat became 28.4 per cent more expensive. What were the causes of this steep increase in wheat prices during the first 2 years of the $19^{\text {th }}$ century? The first cause was a robust demand stemming from the significant rise in population in the previous decade. Second, the pace of agricultural growth seemed to lose momentum and the harvests of 1800 and 1801 were very mediocre ${ }^{10}$. Third, the price of wheat in European markets was very high during these years. This meant that the supply of imported grain for the periphery of the peninsula was reduced and the demand for wheat from the interior areas augmented. Between 1797/1799 and 1800/1801, the yearly wheat prices rose in London, Pisa and Lisbon by 96.6 per cent, 50.3 per cent and 56.6 per cent, respectively $^{11}$.

The upward trend in prices slackened somewhat in 1802-1803: compared with the previous agricultural year the average increase in quoted wheat prices in the eight districts examined was 8.7 per cent. In any case, in the first three agricultural years of the $19^{\text {th }}$ century wheat prices rose significantly and such an increase occurred after an already inflationist period of 15 years. Consequently, the major price rises of 1803/1804 and 1804 /1805 began from a high starting point.

Cereals became even dearer in 1803/1804, reaching levels not seen for more than a century in inland Spain ${ }^{12}$. Between 1802/1803 and 1803/1804, the quoted price for wheat showed an average rise of 63 per cent in the eight areas analysed in this paper and it rose even more in the markets of the northern plateau than in those of the southern plateau. The price rises continued, though less strongly in 1804/1805: the average quoted wheat price was 20.1 per cent higher, compared with the previous agricultural year. In this case, the price increases were less violent in the markets of Castile and Leon than in those of Castile-La Mancha.

Figure 2 shows the different timing of price rises during the subsistence crisis of 1803-1805. In the two areas of Castile and Leon, Medina de Rioseco

${ }^{10}$ In the immense archbishopric of Toledo the average cereal tithe in 1800-1802 was 28 per cent below that of the 2-year period 1798-1799 (Libros de Vestuarios, Archivo de la Catedral de Toledo).

11 www.iisg.nl/hpw/dataphp\#united; Magalhaes Godinho (1955); Malanima (1976, pp. 288-327).

12 In Portugal, specifically in the Evora region, wheat prices soared in 1801 and 1804-1805 (Santos 2012, p. 17). 
TABLE 2

AVERAGE ANNUAL WHEAT PRICES IN SEVERAL CASTILIAN MARKETS, 1799/1800-1805/1806 (IN REALES PER FANEGA)

\begin{tabular}{|l|c|c|c|c|c|c|c|c|}
\hline & León & Zamora & Medina de Rioseco & Avila & Segovia & Toledo & Ocaña & Talavera de la Reina \\
\hline $1799-1800$ & 35.2 & 33.2 & 26.2 & 35.6 & 34.6 & 44.3 & 42.0 & 47.6 \\
\hline $1800-1801$ & 53.8 & 51.4 & 39.4 & 49.1 & 48.6 & 54.0 & 50.2 & 49.9 \\
\hline $1801-1802$ & 68.7 & 59.5 & 55.1 & 59.7 & 62.3 & 69.2 & 71.1 & 62.4 \\
\hline $1802-1803$ & 68.4 & 55.4 & 59.9 & 65.5 & 72.6 & 79.5 & 83.5 & 68.4 \\
\hline $1803-1804$ & 98.5 & 106.8 & 101.0 & 122.8 & 121.8 & 110.1 & 113.2 & 115.9 \\
\hline $1804-1805$ & 108.2 & 119.4 & 99.9 & 144.4 & 133.1 & 152.3 & 151.0 & 163.9 \\
\hline $1805-1806$ & 52.2 & 51.0 & 45.9 & 63.1 & 64.7 & 98.3 & 100.0 & 100.8 \\
\hline
\end{tabular}

Sources: El Correo Mercantil de España y sus Indias; Fernández Hidalgo and García Ruipérez (1989, pp. 335, 337, 339, 348-350). 
FIGURE 2

MONTHLY WHEAT PRICES IN MEDINA DE RIOSECO, SEGOVIA AND TOLEDO FROM JULY 1802 TO DECEMBER 1805 (IN REALES/FANEGA)

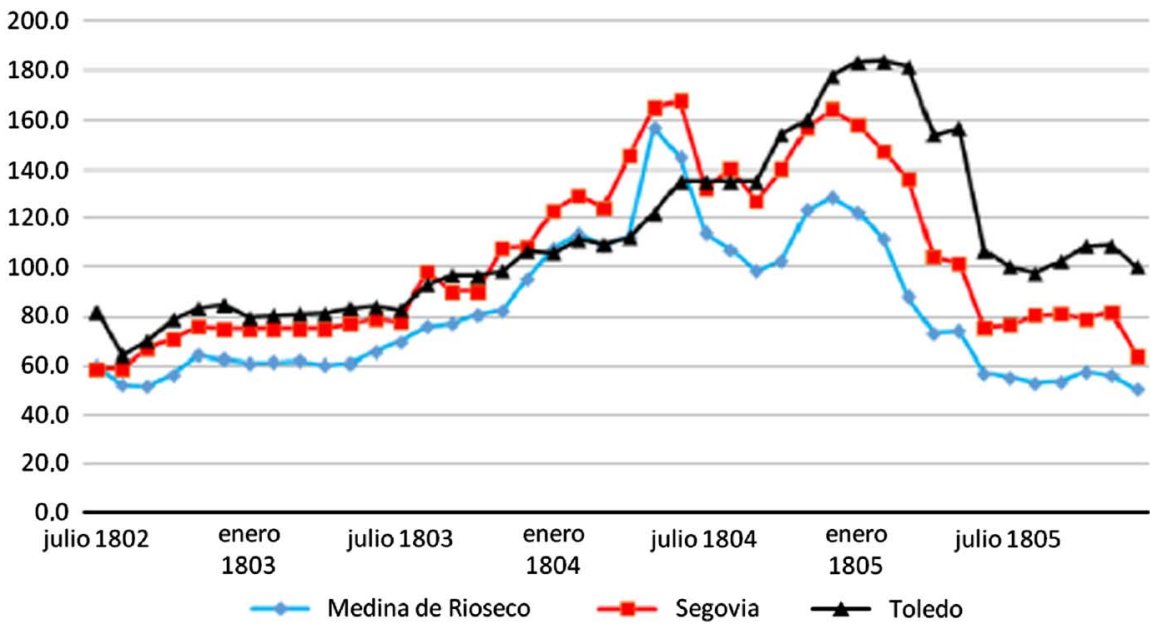

Sources: Fernández Hidalgo and García Ruipérez (1989, pp. 335, 348-350) and Llopis and Sotoca (2005a).

and Segovia, the highest price for wheat was recorded shortly before the 1804 harvest; on the contrary, in Toledo the upward trend of prices lasted until February 1805. As a consequence, the serious nature of the crisis was observed previously in the northern territories of the Meseta (plateau), but the relief from it was delayed by several months on the markets of the southern Meseta.

Grains used to make bread became more expensive than other goods during this crisis. For instance, in Palencia, between 1799-1800 and 1801-1805, the average annual price of wheat showed a 79.2 per cent rise, while the general cost of living rose by 38.3 per cent ${ }^{13}$.

Figure 3 shows that volatility accompanied the increase of cereal prices. Between 1790/1791-1799/1800 and 1802/1803-1811-1812, the standard deviation of logarithmic rates of change in annual average prices of wheat rose by 97.1 per cent in Segovia, by 74.5 per cent in Medina de Rioseco and by 66.3 per cent in Barcelona ${ }^{14}$.

13 Javier Moreno Lázaro provided the series of wheat prices for Palencia. For the cost of living index, see Moreno Lázaro (2002, p. 109).

14 Apart from the greater volatility of prices, another indicator points to the breakup of Spanish and Castilian markets in the early decades of the $19^{\text {th }}$ century: they ceased to be cointegrated (in the last third of the $18^{\text {th }}$ century, they had all followed the same trend and some of them the same cycle as well) (Llopis and Sotoca, 2005b). 
FIGURE 3

STANDARD DEVIATION OF THE LOGARITHMIC VARIATION RATES OF WHEAT PRICES IN 10-YEAR MOBILE WINDOWS IN SEGOVIA, MEDINA DE RIOSECO AND BARCELONA, 1765/66-1834/35

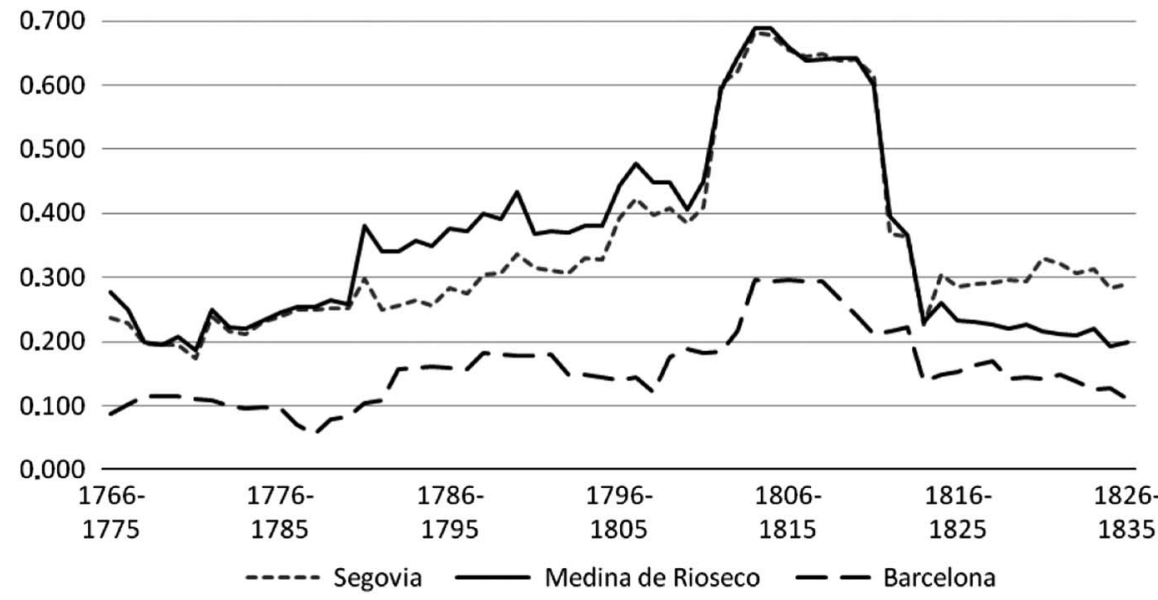

Sources: Actas y Memorias de la Real Sociedad Económica de los Amigos del País de la Provincia de Segovia (1793), tomo IV, pp. 368-405; El Correo Mercantil de España y sus Indias; Mercurial de Segovia, Archivo Municipal de Segovia; Mercurial de Medina de Rioseco, Archivo Municipal de Rioseco; Administración Municipal del Pan, Archivo de la Ciudad Vieja de Barcelona, serie XIV, 3 vols.; Diario de Barcelona.

Why did wheat prices rise so spectacularly in the agricultural years 1803/1804 and 1804/1805? Unquestionably, the harvests of 1803 and 1804 were mediocre, bad or very bad in the two Castiles. In the Segovia area cereal production in these 2 years accounted for only 60 per cent of the average for the preceding years (García Sanz 1977, p. 430) ${ }^{15}$. Still, as fraud in tithe payments seems to have grown in these 2 years, production indices for cereals based on registers containing lists of this tax tend to overstate the fall in the 1803 and 1804 harvests. This being true, the evolution of supply is still not enough to account for the enormous hikes in food shortages in 1803/1804 and 1804/1805.

The authorities, as in previous large scale crises, resorted to imports of wheat to help and support the people ${ }^{16}$. The decision was made too late, by means of a circular from the Consejo de Castilla (Council of Castile), dated

\footnotetext{
15 In the territory of Cuenca harvests were even worse than in Segovia: the 1803 harvest was hardly sufficient to provide seed for the following one (Anes 1970, p. 408).

16 On imports of grain for feeding the city of Madrid in the $18^{\text {th }}$ century, see Castro (1987, pp. 117-118, 171) and Bernardos (2003a, pp. 801-823).
} 
28 July $1804^{17}$, and grain distribution began when the favourable forecasts regarding the next harvest were already leading to grain being brought out of storage and, thus, to a moderation in prices (Anes 1970, pp. 420-421) ${ }^{18}$.

What, then, were the particular characteristics of the foodstuff crisis of 1803-1805? Basically two: first, in 1803, most of the Castilian pósitos (municipal grain stores) had very limited supplies of cereals and lacked the financial resources to buy grain. Consequently, supplying the different villages and cities, except for Madrid, came to depend almost completely on the markets. And second, the functioning of the latter was handicapped by the difficulties involved in getting the grain out to the market because of popular reactions regarding scarcity, but also regarding the privileges enjoyed by Madrid in obtaining supplies of essential goods. This last issue created social unrest, which intensified as price rises worsened. When mediocre or bad harvests occurred the number of net demanders increased, and at the same time the areas supplying the capital also augmented. Many families in Castile had good reasons to be annoyed: (1) the Royal Treasury was spending large sums of money to subsidise bread for the Madrileños ${ }^{19}$; (2) the significant amount of wheat purchases to supply the capital of the monarchy gave way to a notable increase in prices of this cereal and, thus, to serious problems for net demanders of this grain; (3) to face the inadequate supply of transport in the years of acute crisis, the pósito of Madrid resorted to commandeering vehicles and animals, a proceeding that harmed the economic activities of many rural families (Castro 1987, pp. 293-295) ${ }^{20}$.

Throughout the agricultural year 1801-1802 there were popular protests against the shortages and high prices, which on some occasions were protected and encouraged by municipal authorities. In March 1802, women from the slums of the city of Segovia rioted and prevented the commissioners from Madrid's pósito from taking out the wheat they had ordered (García Sanz 1977, p. 431). In the final months of the agricultural year 1801/1802 riots took place in Tembleque and Getafe because grains were being taken out of the municipal barns (Pérez Moreda 1980, p. 377). Around the same date, high prices and the extraction of grain generated great unrest in Villanueva de los Infantes and Casas Ibáñez ${ }^{21}$. On 20 May 1802, women and

17 AHN, Consejos, libro 1502, no 72. The circular of 22 February 1804, already referred to the need to use imports to provide the villages with wheat (AHN, Consejos, libro 1502, no 24).

18 On 26 November 1804, the government signed a contract with Gabriel Julian Ouvrard — an important businessman and agent of Napoleon whose speciality was supplying armies — to import large amounts of cereals. This agreement was part of the complex and tense financial relationships at that time between the Spanish monarchy and the French state (Marichal 2007, pp. 156-163).

19 Between 1785 and 1805, subsidies for Madrid's bread exceeded 135 million reales (Castro 1987, p. 266).

${ }^{20}$ In 1802, for example, there was an embargo on droves to provide Madrid with wheat (Bernardos 2003b, p. 163).

21 Anes (1970, p. 405); Pérez Moreda (1980, p. 377); AHN, Consejos, Sala de Gobierno, file 2127, record 3 . 
children from Calzada de Calatrava prevented ««merchants and hoarders» from entering the town ${ }^{22}$.

The popular struggle against grain being taken away from barns intensified in 1803-1804 and 1804-1805. We provide two examples to illustrate this. On 17 January 1804, the local council of Valdemoro informed the Consejo de Castilla that in villages of the region the people were stopping the extraction of the wheat stockpiled and partially paid for by the bakers of that village ${ }^{23}$. On 4 February 1804, the local council of Cebolla requested the Consejo de Castilla not to take grain from that village, not even to supply the Court; they requested also that villagers should have priority over any surplus of local bread ${ }^{24}$. To sum up, the cereal market was strangled in $1803 / 1804$ and $1804 / 1805$ as a result of popular uprisings, sometimes under the protection of local authorities, to stop grain being taken out of the stores. There is little doubt that the very poor performance of spatial arbitrage of prices, at a time when the operating capacity of municipal barns had been severely reduced (Anes 1969, pp. 88-94), contributed to shortages and famine in those years that reached dimensions unknown for centuries. Moreover, agricultural producers, basically due to need, but also to obtain the maximum benefit during a period of very high prices, committed fraud in paying the tithe on a greater scale than they had done in previous years. Therefore, a higher percentage of the product of the wheat went to family consumption and that available for the market diminished.

In synthesis, the very high prices of 1803/1804 and 1804/1805 were the outcome of two consecutive bad harvests, but also of other factors, among which we can list: (1) the poor agricultural development of the preceding years which had led to a fall in private grain stocks; (2) the inability of the government to accelerate cereal imports; (3) the limited capacity of the pósitos, whose resources had been depleted by the constant demands of the Royal Treasury; and (4) most of all, the strangulation of the wheat market due to the barriers raised by net demanders of grains, who were not willing to allow merchants to remove grain from the local barns. Such actions were at times tolerated, protected or approved by municipal governments. In summary, a multiplicity of causes led to a collapse of the traditional supply system in the interior of Castile between 1803 and 1805 .

Table 3 shows that between 1802 and 1806, at least 2 years show an overall mortality crisis in Albacete, Ciudad Real, Avila, Guadalajara, Burgos, Palencia and Zamora ${ }^{25}$.

${ }^{22}$ AHN, Consejos, Sala de Gobierno, file 2127, record 3.

23 AHN, Consejos, Sala de Gobierno, file 2412, record 13.

24 AHN, Consejos, Sala de Gobierno, file 2364, record 23.

25 To determine the mortality crisis we have used the provincial series of obituaries. A crisis year is one when the difference between the deaths in that year and the truncated average of the same in the previous five and the subsequent five (eliminating the two maxima and the two minima) reaches or exceeds 25 per cent of the latter. The excess deaths are expressed in percentages. 
TABLE 3

OVERMORTALITY IN SEVERAL CASTILIAN PROVINCES, 1802-1806 (\%)

\begin{tabular}{|c|c|c|c|c|c|c|c|}
\hline $\begin{array}{l}\text { Years or } \\
\text { period }\end{array}$ & $\begin{array}{c}\text { Albacete } \\
\text { (9 localities) }\end{array}$ & $\begin{array}{l}\text { Ciudad Real } \\
\text { (11 localities) }\end{array}$ & $\begin{array}{c}\text { Avila } \\
\text { (22 localities) }\end{array}$ & $\begin{array}{l}\text { Guadalajara } \\
\text { (19 localities) }\end{array}$ & $\begin{array}{c}\text { Burgos } \\
\text { (40 localities) }\end{array}$ & $\begin{array}{c}\text { Palencia } \\
\text { (17 localities) }\end{array}$ & $\begin{array}{c}\text { Zamora } \\
\text { (17 localities) }\end{array}$ \\
\hline 1802 & 28.0 & - & - & - & - & - & 43.9 \\
\hline 1803 & 97.4 & 60.6 & - & 36.5 & 62.9 & 66.9 & 74.9 \\
\hline 1804 & 41.5 & 61.5 & 79.1 & 212.0 & 208.2 & 212.8 & 114.5 \\
\hline 1805 & - & - & 38.3 & 32.6 & - & 51.5 & 31.0 \\
\hline 1806 & - & - & 28.2 & - & - & - & - \\
\hline $1802-1806$ & 167.0 & 122.1 & 145.7 & 281.1 & 271.0 & 331.2 & 264.3 \\
\hline
\end{tabular}

Sources: Death registers of diverse localities, Diocesan Archives of Albacete, Ciudad Real, Avila, Sigüenza, Burgos, Palencia and Zamora. 
Overmortality is to be found in two of the seven provinces examined in 1802, in six in 1803, in seven in 1804, in four in 1805 and in one in 1806. The average severity was 35.9 per cent in $1802,66.5$ per cent in 1803 , 132.8 per cent in $1804,38.3$ per cent in 1805 and 28.2 per cent in 1806 . As a result we can state that 1803 and, particularly, 1804 constitute the heart of this crisis. The intensity of the crisis was clearly higher in Palencia, Guadalajara, Burgos and Zamora than in Albacete, Avila and Ciudad Real. The figures in Table 3 suggest that the provinces of the northern plateau suffered more from these demographic adversities than those of the southern plateau.

The mortality crisis at the dawn of the $19^{\text {th }}$ century had a greater effect on the adult population than on the infant one: in the 5-year period of 18021806, overmortality for the former rose to 514.4 per cent in Burgos, 488.4 per cent in Guadalajara, 484.9 per cent in Palencia, 311.5 per cent in Zamora, 280.8 per cent in Avila, 231.3 per cent in Albacete and 170.9 per cent in Ciudad Real; in that same period, for the latter, it rose to 168.1 per cent, 162.5 per cent, 192.9 per cent, 264.4 per cent, 77.1 per cent, 89.6 per cent and 114.1 per cent, respectively ${ }^{26}$.

What was the damage caused by the crisis in the period 1802-1806 as a percentage of the Castilian population? If the average death rate in the interior of Castile averaged 38 per cent at the end of the $18^{\text {th }}$ century ${ }^{27}$, overmortality in that 5-year period would have wiped out 6.3 per cent of the population of Albacete, 4.6 per cent of that of Ciudad Real, 5.5 per cent of that of Avila, 10.7 per cent of Guadalajara, 10.3 per cent of Burgos, 12.6 per cent of Palencia and 10.0 per cent of Zamora. If the sample of provinces studied happens to be representative, human losses would mean 8.8 per cent of the total population of the two Castiles. Bearing in mind the relative lack of births in the period 1802-1806, it is quite possible that the decline in the population would have exceeded 10 per cent in Castile during this 5-year period.

This demographic bloodletting at the beginning of the $19^{\text {th }}$ century was a result of the temporary coincidence of a severe subsistence crisis and the spread of important epidemics of tertian fever, typhus, and, perhaps, dysentery (Pérez Moreda 1980, p. 381) ${ }^{28}$.

\footnotetext{
(footnote continued)

In Grupo Complutense de Historia Económica Moderna (2013) it is explained in detail why we use provincial rather than local series and why a lower overmortality threshold is used to determine the crises than those used by Flinn (1974) and Del Panta and Livi Bacci (1977).

${ }^{26}$ In the south of Sweden, between 1750 and 1860, juvenile and adult mortality were rather more sensitive to lack of food than child mortality (Drive et al. 2011).

27 In inland Spain, the death rate was quite close to 40 per cent in the second half of the $18^{\text {th }}$ century (Pérez Moreda 1980, p. 137).

${ }_{28}$ Tabardillo (typhus) and tertian fevers accounted for a high percentage of the huge mortality in the province of Cuenca (Reher 1980, p. 49).
} 
The Yebra parish priest specified the factors behind the unusual drop in population in the territory of La Alcarria:

«En el año de 1804 fallecieron 290 personas en esta parroquia de Yebra: mortalidad asombrosa, originaria de tercianas y tabardillos, todos malignos y epidémicos: y de escasez de la cosecha: el pan valió a 30 quartos, el aceite a 100 reales, el cáñamo a 100 reales, el trigo bueno a 160 reales, el carnero a 25 cuartos (muy probablemente, la libra), la cebada a 100 reales, la avena a 65 reales ${ }^{29}$.

Hunger and high prices have tended to occupy the main place in the 18031805 crisis, but the great epidemics of tertian fever and typhus seem to have played a crucial role in this demographic disturbance and our knowledge of its origin, territorial distribution, morbidity and lethality is still insufficient.

The great demographic disasters were provoked fundamentally by rises in the number of deaths, but during these episodes the number of conceptions and, a short time later, births tended to fall noticeably. In this manner the natality crises have constituted a habitual ingredient in demographic setbacks. The quantification of the natality crises enables us to know the precise magnitude of the great population «shocks» during the Ancien Régime.

In Table 4 we have shown the intensity of the natality crises in the seven provinces examined in the 4-year period of $1803-1806^{30}$.

If we compare the figures in Tables 3 and 4, we can observe a certain correspondence between the magnitude of the mortality crisis and that of natality. In both cases, Palencia figures as the area most affected by the demographic disaster in the early part of the $19^{\text {th }}$ century, but the distance between this province and the next one, Guadalajara, is much greater in the case of the natality crisis than in that for mortality. Burgos and Zamora are in third and fourth place in both rankings, but in relative terms these two provinces stand out mainly for the magnitude of the mortality crises than for the natality decline. Avila, Albacete and Ciudad Real are in the last places. In short, an examination of the year-on-year fluctuations in the number of baptisms also suggests that the demographic crisis in the early years of the $19^{\text {th }}$ century was more devastating in the northern plateau than in the southern one.

Since we have series of baptisms and deaths for all the places of the provincial samples, we can build a rather complete indicator of the effects of the demographic crises, one which incorporates two of their basic elements: the rise in deaths and the fall in births. The proposed index, which we have reflected in Table 5, is the aggregate annual vegetative balance of the crisis period.

\footnotetext{
29 Death registry of Yebra, Diocesan Archive of Sigüenza.

30 Percentage decrease in the number of baptisms compared with the truncated average for 11 years (leaving uncounted the crisis year, the two maxima and the two minima). We have considered as crisis years all those in which the decline reached or exceeded 10 per cent.
} 
TABLE 4

NATALITY CRISES IN SEVEN CASTILIAN PROVINCES, 1803-1806 (\%)

\begin{tabular}{|l|c|c|c|c|c|c|c|}
\hline $\begin{array}{l}\text { Year or } \\
\text { period }\end{array}$ & Albacete & $\begin{array}{c}\text { Ciudad } \\
\text { Real }\end{array}$ & Avila & $\begin{array}{c}\text { Guada- } \\
\text { lajara }\end{array}$ & Burgos & Palencia & Zamora \\
\hline 1803 & 20.8 & - & - & 15.4 & - & 18.7 & - \\
\hline 1804 & 13.4 & 14.2 & 12.4 & 25.9 & 35.0 & 30.7 & 20.4 \\
\hline 1805 & 17.9 & 19.2 & 38.0 & 42.4 & 27.5 & 65.2 & 42.3 \\
\hline 1806 & - & - & - & - & - & 12.9 & - \\
\hline $1802-1806$ & 52.2 & 33.4 & 50.4 & 83.7 & 62.5 & 127.5 & 62.6 \\
\hline
\end{tabular}

Sources: Books of baptisms of diverse localities, Diocesan Archives of Albacete, Ciudad Real, Avila, Sigüenza, Burgos, Palencia and Zamora.

TABLE 5

ACCUMULATED ANNUAL VEGETATIVE BALANCES IN SAMPLES FOR SEVEN CASTILIAN PROVINCES, 1802-1806 (\% OF THE BAPTISED)

\begin{tabular}{|l|c|c|c|c|c|c|c|}
\hline Period & Albacete & $\begin{array}{c}\text { Ciudad } \\
\text { Real }\end{array}$ & Avila & $\begin{array}{c}\text { Guada- } \\
\text { lajara }\end{array}$ & Burgos & Palencia & Zamora \\
\hline $1802-1806$ & -175.7 & -252.0 & -380.7 & -650.6 & -451.1 & -942.0 & -440.3 \\
\hline
\end{tabular}

Sources: Books of baptisms and deaths in various places, Diocesan Archives of Albacete, Ciudad Real, Avila, Sigüenza, Burgos, Palencia and Zamora.

Figures in Table 5 show that Guadalajara and, especially, Palencia were the territories which lost more population. In the following group there were three provinces: Burgos, Zamora and Avila. Finally, the demographic fall was milder in Albacete and Ciudad Real than in the other territories.

Altogether, the demographic catastrophe in the interior of Spain was widespread in the early years of the $19^{\text {th }}$ century, but contrasts in the intensity of the disaster in the different territories of Castile were quite important.

\section{GOVERNMENT MEASURES AGAINST THE CRISIS AND POPULAR REACTION}

The government's reaction to the crisis at the beginning of the $19^{\text {th }}$ century was rapid, forceful and rather daring. Its primary aims were to avoid strong popular uprisings and to preserve the basic institutions of the Ancien Régime. To achieve these aims, the Crown understood that it would have to travel through virgin territory. Nonetheless, by no means was everything 
new in the government's response to the crisis: most of the measures adopted followed the time-honoured pattern of intensifying state intervention in food supply.

The relative speed with which the government reacted was a result of the gravity of the crisis and the perception that sectors of the population were not prepared to stand by passively quite as much as on previous occasions (the disturbances of 1802 had served as a serious warning to the authorities). The prompt adoption of measures was not unconnected with a more rapid circulation of economic and social information (The Correo Mercantil de España $y$ sus Indias is fair testimony of this feat). Also important was the greater ability of the monarchy to act thanks to the reinforcement of administrative structures in the previous half century.

Numerous writings immediately before the 1803-1805 crisis reveal the enormous concern of local authorities regarding the serious local instability and the grave consequences that might follow the outbreak of popular movements. For example, the authorities of San Clemente and Villarobledo asked the Consejo de Castilla to endorse the measures they had adopted in order to prevent greater trouble: the registration of all the barns, the right of the locals to bid for any grain left over by the most affluent and the prohibition of the extraction of grain without the authorisation of local justice; moreover, they demanded that the cereals should be appraised. At about the same time, residents of Casas Ibañez argued that if the monarch did not adopt all the measures previously mentioned, the kingdom would face a «rebelión y demás funestas consecuencias que de ordinario acarrea, como en otros reinos han tocado por experiencia» ${ }^{31}$. Aside from some exaggeration, countless testimonies show that the foundations of social order no longer had the strength of yore.

Among the innovative and daring government measures for the political parameters of the Ancien Régime we will highlight three: retaining, up to a maximum of one fifth, all the tithes with the intention of supplying grain to the villages (Royal Charter of 8 September 1803); reduction of one third, quarter or fifth, according to the provincial calculation of the 1803 harvest, of the land rents which had to be paid by tenant farmers and lessees (Royal Order of 26 December 1803); and, finally backing a public works programme managed and financed by local councils (Circular of 7 October 1804) ${ }^{32}$.

The government understood that the problem of supplying cereals for bread making was extremely serious and that the traditional regulations were insufficient. Consequently they adopted an exceptional and relatively radical measure soon after the meagre 1803 harvest, keeping back up to a fifth of the tithe mass. The juntas del pósito or, failing that, the local councils were the bodies charged with carrying out this regulation, and the

31 AHN, Consejos, Sala de Gobierno, file 2127, record 3.

32 AHN, Consejos, book 1501, no. 127; AHN, Consejos, book 1502, no. 80; AHN, Consejos, Sección de Gobierno, file 2423, record 2 and file 2980, record 15. 
agricultural product kept back had to be purchased at market prices either cash down or the following year after harvesting. Those enjoying decimal rights tried to prevent the application of this measure. Paying in cash was difficult to enforce because the local councils were suffering severe financial difficulties ${ }^{33}$ and it was utopian to think that 1 year later councils would be able to meet their commitments ${ }^{34}$. However, the main harm for those taking part in the decimal distribution was the breakup of the obligatory nature of the distribution of tithes at a time when fraud concerning this ecclesiastical tax was increasing greatly. This measure consolidated a path already followed since the late $18^{\text {th }}$ century: the monarchy was resorting to Church income and property to tackle their severe financial imbalances and the great subsistence crisis (García Sanz 1977, pp. 448-449; Ruiz Torres 2007, p. 605). Therefore, before 1808 the relations between the dominant lay groups and the ecclesiastical ones had already begun to deteriorate.

The reduction of rent payments by tenant farmers and lessees was also a brave measure that had never been tried by the monarchy. The Crown tried to act as mediator in an inevitable conflict, since a significant number of agricultural producers who had the usufruct of agrarian land were not willing to pay the land rent stipulated by their respective contracts if that payment compromised to a great extent the suppIy of cereals for their family and/or for their next sowing. We could also detect that small farmers were not resigned to their fate: their resistance to pay the rent for the land went a good deal further than in previous crises. The above-mentioned Royal Order of 26 December 1803 granted a certain amount of legal backup to the claims of tenant farmers and lessees ${ }^{35}$. The fact that the monarchy went so far in this question could not be divorced from the fact that the alternative to non-intervention implied a high cost in terms of risking virulent social strife.

Under-employment and unemployment soared because of the slump in the level of economic activity in 1803 and 1804 due to the sparse harvests and the high morbidity as a result of tertian fevers ${ }^{36}$, as well as the strangulation of trade as a consequence of obstacles imposed by local authorities and inhabitants on movements of grain from one place to another. The aforementioned government measures did not guarantee that many families would earn enough to be able to pay for essential foodstuff. This problem was very acute in the case of families whose income depended essentially on wages. More than 200 persons found themselves in extreme need in

33 On the council's financial problems in those years, see García García (1996, pp. 259-275).

34 AHN, Sala de Gobierno, file 2414, record 6 and file 2391, record, 22.

35 On the struggle of lessees and poor tenants of the Monastery of La Santa Espina during this period of crisis in order to reduce the land rents they had to pay to this institution, see López García (1990, pp. 448-450).

36 For example, at the beginning of 1804 the Junta de Socorros (Charity Board) of Peñalén indicated that quite a few areas could not be sown because of the high mortality brought on by the tertian fevers (AHN, Consejos, Sala de Gobierno, file 2391, record 19). 
Carrascosa del Campo and a similar number faced an analogous situation in Hinojosa de la Orden ${ }^{37}$. In Peñalén, «por las calles se hallan los niños, mujeres y ancianos traspellados de hambre, y ya se ha verificado hallar cadáveres por los filos agudos de la miseria, y causa horror este apuro tan doloroso ${ }^{38}$. By early 1804, the jail of Carrascosa del Monte was full of the wives and children of wage earners, as well as orphans who had cut firewood illegally in the forests. The judge and the local attorney expressed to the Consejo de Castilla how uncomfortable they felt making decisions under such circumstances:

«ni bien se puede llevar a efecto el rigor de la ordenanza, ni tampoco pueden disimularse estos excesos. A la verdad señor que a la vista de una anciana viuda con tres hijos cargados de leña, descalzos, y en una casi total desnudez, víctimas del hambre y del rigor de la intemperie, no puede menos de enternecerse hasta las piedras» ${ }^{39}$.

This dismal panorama incited the government, in the autumn of 1803, to undertake a general public works programme to alleviate unemployment in agriculture, reduce the number of beggars, control migrations and try to prevent public order disruptions. The goal was to provide employment and, consequently, an income to many families whose earnings from wages had slumped. This plan was to be managed and financed by the local councils. Since the vast majority of the councils lacked the necessary funds to deal with the cost of public works, the government circular foresaw that the towns and villages could propose the most suitable expedients to fund them to the Consejo de Castilla. Moreover, the Consejo de Castilla demanded that the clergy and the rich should contribute to the funding of this plan.

The works most frequently proposed by the towns and villages were: repairing roads or paths; building or repairing one or more bridges; building, repairing or paving the streets; rebuilding the Town Hall; repairing or improving fountains; cleaning, widening or repairing riverbanks. The councils most often requested sources of revenue were: ploughing up land or fencing it off; leasing the properties of councils and making charcoal from firewood. Some areas sought permission to sell land and forests belonging to the council ${ }^{40}$.

37 AHN, Consejos, Sala de Gobierno, file 2355, record 20, and file 2370, record 28.

38 AHN, Consejos, Sala de Gobierno, file, 2391, record 19.

39 AHN, Consejos, Sala de Gobierno, file 2355, record 20.

40 AHN, Consejos, Sala de Gobierno, file 2173, record 48; file 2340, record 3; file 2412, record 32; file 2553, record 20; file 2372, record 13; file 2410, record 9; file 2358, record 23; file 2429, record 29; file 2408, record 11; file 2355, record 20; file 4025, record 94; file 2391, record 19; file 2412, record 3; file 2377, record 14; file 2412, record 24; file 2410, record 5; file 2408, record 6; file 2346, record 6; file 4026, record 10; file 2370, record 28; file 2328, record 26 . 
The government's public works policy could not offer an effective cure for unemployment and hunger in the whole area of Castile, but it did provide some relief for the critical situation suffered by part of the population of some towns and villages ${ }^{41}$. This insufficiency was due, first of all, to the lack of resources on the part of the monarchy, hindering the direct funding of projects; therefore, the Crown depended on local authorities to develop its measures. Second, the coffers of the councils were usually empty and finding and making use of expedients that would be sufficient to finance significant works was difficult and time-consuming. Third, carrying out fiscal policy normally involves considerable delay and, logically, such delays took even longer in societies, like those of the Ancien Régime, where the processing of legislation and the circulation of information were slow. In any case, it is of enormous interest to note that the government, in the autumn of 1803 , began to assume important responsibilities, perhaps for the first time in the history of Spain, to improve the levels of activity and employment.

In some European countries, in the 1816-1817 crisis, the last to affect the whole area of the Old Continent, an expansive fiscal policy was applied, similar to the one that had already been tried out in Spain in 1803-1805 (Post 1976, p. 25; Pérez Moreda 1980, p. 379). Later, in Sweden in the 1820s and 1830 s, a policy of state-funded public works was applied when demand for work in the private sector diminished. This type of contracyclical policy can indeed be regarded as a precedent, albeit a remote one, of the Keynesian demand management policies (Bengtsson 2004, pp. 140-141).

Along with this small number of innovative measures, most of the legal regulations issued by the government had already been used in previous crises. Here, for reasons of space, we will only mention some of the most important. We will organise them by subject, and we will make a brief comment on how these regulations were applied.

To face the severe subsistence crisis in the early years of the $19^{\text {th }}$ century, the government intervened more strongly in cereal markets and tried to guarantee essential food supplies for Madrid. Already in the Circular of 11 November 1802, before prices shot up, the Crown ordered that for the time being harvesters and those holding grain stocks were obliged to sell wheat surpluses held in their granaries for public supply at market prices ${ }^{42}$. The riots that took place in several places in 1802 persuaded the authorities to grant this prerogative to the villages, but this only created another obstacle to free trade, by deterring the freedom of time and place for the sale of these products.

41 See the cases of Villoslada de Cameros, Palencia, Avila, Burgos, Molina de Aragón and the areas situated between Dueñas and Villamuriel (in the Canal de Campos there were more than 3,000 labourers working during the winter of 1803-1804) (Peset and Carvalho 1972, pp. 231-233).

42 AHN, Consejos, book 1501, no. 61. 
The Consejo de Castilla, in order to have available up-to-date information and not to delay the announcement of measures geared to halting the skyrocketing prices, requested judges and the clergy to inform them about the amount of cereals stored in public and private granaries and about their forecasts for the 1804 harvest, and sent a monthly report of what amount of grain and seeds would be needed by each place ${ }^{43}$.

Another rung in the scale of intervention was climbed with the circular of 19 September 1803: this regulation established wheat taxes on all the markets located in a radius of ten and twenty leagues around Madrid. The maximum price set for top quality cereal was 100 reales per fanega for the wheat coming from the former area and of ninety reales in those places located in the latter ${ }^{44}$. Popular pressure and that of some local authorities led the government to establish, in May 1804, a system of flexible assessment which would take into account the situation of the different local markets. The Royal Order of 21 May 1804 stipulated that until the next harvest the Juntas de Beneficiencia (Charity Boards) or, failing that, the mayors were to set a "fair» price for the grains, bearing in mind the cost of imported cereals at the ports and the cost of transporting it from the coast to the corresponding town or villages ${ }^{45}$.

Since the interventionist measures and the retaining of up to a fifth of the tithe mass did not solve the problem of supplying food to the towns and villages, the government resorted to importing grain. Nonetheless, the arrival and distribution of foreign grain was somewhat delayed. In addition to the usual problems which normally slowed down this type of operations, there was, in 1804, an outbreak of yellow fever in Andalusia, Murcia and Valencia (Anes 1970, pp. 417-418).

The government also encouraged the charitable activity of Church institutions and wealthy families. The Royal Order of 18 September 1803 stipulated that archbishops, bishops and Economic Societies should distribute cheap food financed by the affluent. Chiefly in cities, one of the main measures taken to reduce hunger was the handout of foodstuffs by Juntas de Caridad, Juntas de Beneficencia (Beneficence Boards) and Sociedades Económicas de Amigos del País (institutions that had been created by the enlightened) ${ }^{46}$.

The Circulars of 8 October and 26 December 1803 ordered, as a means of combating outbreaks of tertian fever, the establishment of Health Boards in all villages and towns. Their main duties were: to cure and feed the sick,

43 Circulars of 12 August 1803 and 11 July 1804; Order of May 1804 (AHN, Consejos, books 1501, nos 116 and 117, and 1502, nos 63 and 51), respectively.

44 AHN, Consejos, book 1501, no. 133.

45 AHN, Consejos, book 1502, no. 54.

46 AHN, Consejos, book 1501, no. 130-131 (Pérez Moreda 1980, pp. 377-378). On the distribution of cheap meals in Madrid, see (Demerson 1969, pp. 119-137). In Salamanca, the Junta de Socorro collected food to supply free bread to 200 poor people and very cheap bread to 6,000 artisans and labourers at the beginning of 1804 (Peset and Carvalho 1972, pp. 241-243). 
particularly artisans and labourers; to take care of the most essential public works "of policing and cleaning» (especially the draining of stagnant water); and, finally, to bury the dead in cemeteries outside the towns ${ }^{47}$.

For various reasons, government legislation to tackle the crisis of 1803-1805 was doomed to achieve poor results. In the first place, the economic policy put into action was rather a mixture, combining traditional measures of a strongly interventionist nature and other more innovative ones geared to a less unfair share-out of the costs of the crisis among the different social groups. Furthermore, most of the latter had little success: on the one hand, the shortage of funds and the tiresome administrative paperwork hindered the development of municipal plans for public works; on the other hand, the poor harvests and increasing fraud in tithe payments resulted in too small quantities of products withheld from this ecclesiastical tax ${ }^{48}$.

Second, the monarchy lacked the administrative and financial resources to carry out the majority of the measures enacted. Collaboration of the local authorities and oligarchs was vital for the application of nearly all the government-approved rules. Despite the expansion of the Central Administration in the $18^{\text {th }}$ century, it was still quite fragmented in Spain at the beginning of the $19^{\text {th }}$ century (Grafe 2012, pp. 213, 219, 238). Furthermore, the interests of royal government and of local authorities differed quite often. For the monarchy, supplying wheat to Madrid was the top priority, whereas local authorities were subjected to various pressures: from the well-off, whom they basically represented, and who did not wish to sacrifice the maximum profit they could gain from their cereal surpluses in a situation of acute shortage; from net cereal demanders - small agricultural producers, labourers and artisans - who in those years of poor or very inadequate harvests demanded privileged access and at appraised price to the wheat surplus of the harvesters and local rentiers; and, on occasions, from industrial employers. This was the case of Segovia, where industrialists requested a subsidy for essential foodstuffs to prevent an increase in their labour costs in years when demand for manufactured goods fell sharply ${ }^{49}$. Conciliating all these interests and those of the Administration proved impossible. There was an additional difficulty: in order to finance the wars against France and England and maintain public credit, the

47 Circulares de 8 de octubre y de 26 de diciembre de 1803, AHN, Consejos, book 1501, no. 139, and book 1502, no. 80. In fact, the first of these circulares intended to implement a previous one that had been enacted on 13 August 1787, in the midst of a previous malaria outbreak (Pérez Moreda 1984, pp. 333-354).

48 Apart from the poor harvest and the rise in fraud, the amounts were sparse because retentions normally applied only to parts of the tithe mass. See the cases of Majaelrayo, Malaguilla, Sigüenza, Cebolla, Calzada de Calatrava, Peral and Escamilla in AHN, Consejos, Sala de Gobierno, file 2378, records 43 and 41; file 2404, record 1; file 2364, record 23; file 2358, record 29; file 2408, record 18; file 2391, record 22; file 2455, record 20.

49 The adventures of the authorities of the city of Segovia are splendidly described in García Sanz (1977, pp. 435-437). 
monarchy had emptied the coffers of the pósitos (municipal barns), local estates and various charitable institutions. Therefore, the ability of the councils and charitable institutions to support the government in these tasks was fairly limited.

Third, the orders enacted by the monarchy to tackle the crisis of 1803-1805 gave rise to fierce confrontations over their application and these often led to infringements, more or less generalised, of the government regulation or to its denaturation. The principal conflicts occurred in the heart of rural communities between the well-off and oligarchies, on the one hand, and most of the villagers - usually net customers for grain in those difficult years - on the other. Nevertheless, tensions also flared between rural communities: frequently between villages with a surplus of cereals and areas which were seriously short of them. So, for instance, Valdemoro complained to the Consejo de Castilla, in early 1804, asking that the authorities of neighbouring villages with large surpluses should not prevent the export of wheat ${ }^{50}$.

The net demanders of grain requested that this produce should not be removed from the corresponding place; that there should be no exonerations and cases of discrimination in the registers and embargo of cereals ${ }^{51}$; and that wheat should be sold at a fixed price. Logically, these claims clashed head-on with the interests of the large rentiers and harvesters. The municipal authorities tried to mediate in order to maintain social order; this led them to forbid grain being taken out of their towns and villages or to ask the Consejo de Castilla to authorise this. The final result of the whole episode was that the interterritorial flows of cereals, except for those aimed at supplying Madrid $^{52}$, plummeted, among other reasons because the Consejo de Castilla was sensitive to the shocking pleas and petitions of numerous villages ${ }^{53}$. This gave rise to the temporary collapse of the grain market in Castile and an even greater increase in prices over and above what had been caused by the scarce harvests of 1803 and 1804, and the very scant stocks in nearly all the pósitos at the start of these years of penury. As indicated by Concepción de Castro, the 1803-1805 crisis first eliminated what remained of the liberalisation of the grain market, but also, subsequently, led to the definitive collapse of the traditional supply system, causing the freeing up of commerce of grains and bread in the summer of 1805 (Castro 1987, pp. 173, 236).

50 AHN, Consejos, Sala de Gobierno, file 2412, record 13.

51 This often occurred in those years when there was an embargo in many places on wheat, coal and other products for supplying Madrid (Anes 1970, p. 411).

52 In September 1803, commissioners and agents of the pósito of Madrid regained the right of first refusal in grain storage. The privileges, subsidies and intense political pressure of the monarchy explain that the shortages and high prices were less severe in the capital city during the 1803-1805 crisis than in most areas of Castile (Castro 1987, pp. 174, 234).

53 Among many others, those of San Clemente and Villarobledo (AHN, Consejos, Sala de Gobierno, file 2127, record 3). 
The ban on the extraction of cereals from villages and towns and the setting of fixed prices for them was not always obeyed by the local wealthy and oligarchs. In Talavera de la Reina in early 1804, for example, some large harvesters and rentiers were supplying the area with wheat at the price of 120 reales per fanega, but other important owners of cereals were illegally selling this product in other places and obtaining 130 reales or more for each fanega ${ }^{54}$.

Why did so many local authorities protect and promote the ban on grain extraction and the setting up of a fixed price for its sale to the inhabitants of their respective towns and villages? Undoubtedly the posts they held compelled them to try to keep order and make sure that the places they ruled had enough food, but in this crisis of 1803-1805 their actions were much tougher and forceful than they had been in the past. Their greater commitment was probably a reaction to the mobilisation of large sectors of the population, who were no longer willing to tolerate hunger and the deterioration of their health, and the Dantesque scenes they often had to contemplate in their towns or villages. An example of this was the account that the judge and the council of the village of Toboso presented, on 11 November 1803, to the governor of Ocaña. The epidemic of tertian fever and the shortage were provoking a large number of deaths among the «hapless» labourers:

"por aquella secuela de la suma miseria que tiene consternado al vecindario, en una suma aflicción y escasez de frutos, y carestía de los víveres de primera necesidad; de manera que si no se les proporciona algún alivio en el invierno próximo, según el dictamen de los físicos, va a perecer de necesidad y por falta de socorro de medicinas, y alimentos la tercera parte del vecindario ${ }^{55}$.

The posture, often one of firmness, adopted by council authorities in favour of the prohibition of the extraction of grain from the villages and the establishment of fixed prices for these products must have opened up certain cracks within dominant local groups.

The violence of the 1803-1805 crisis and the economic policies of the government and the town halls fuelled confrontations between the different social groups. The monarchy attempted to ensure, albeit at a very high political and financial cost, that Madrid would have a sufficient supply of basic foodstuffs, but it also attempted to mediate in the above-mentioned conflicts of interest. When the Consejo de Castilla had to settle conflicts concerning grain supplies during the 1803-1805 crisis, it almost always ordered authorities of the villages to obey the regulations contained in the

\footnotetext{
54 AHN, Consejos, Sala de Gobierno, file 2410, record 10.
}

55 AHN, Consejos, Sala de Gobierno, file 2410, record 9. 
Circular of 11 November 1802: (1) local inhabitants had priority in the purchase of grain surplus from local harvesters and rentiers, and the price of it was to be the same given to bakers; (2) local authorities were not to buy wheat when there was enough supply to meet the needs of the corresponding town or village for a whole month; and, (3) the towns were not to hold wheat stockpiled by the pósito of Madrid or by another pósito, and should not impede the harvesters from trading their surpluses of cereals ${ }^{56}$. However, the monarchy was overwhelmed by events: it failed in its attempt to prevent the collapse of the cereal market, since allowing the inhabitants preferential access to surplus wheat in each place and keeping grain moving from the areas with less shortage to those where the lack of foodstuffs was most severe were two goals that could not be reconciled. Government legislation in supply matters was often infringed by private individuals and local councils, and the actions taken by local authorities were a reaction to the strong pressure from the populace and certain private interests.

The 1803-1805 crisis provided clear evidence that political power, in spite of the strengthening of the Central Administration in the $18^{\text {th }}$ century, was still quite fragmented in Spain in the early $19^{\text {th }}$ century.

\section{CONCLUSIONS}

The 1803-1805 crisis was not just another of the many crises recorded in the Ancien Régime. It stood out because of its enormous magnitude: it affected the whole territory of Castile, it lasted for more than 2 years, and caused the loss of almost 15 per cent of the population of the two Mesetas.

It also stood out for its causes: apart from the low level of grain stocks at the end of the agricultural year of 1802/1803, the bad harvests of 1803 and 1804 and the considerable spread of important epidemics - largely brought about by the rise in hunger-based migrations - the social disasters of these years were the result of the malfunctioning of two basic institutions, pósitos and markets. The municipal granaries had recently been decapitalised to maintain public credit, whilst the spirited public reaction to hunger and high prices led to serious disruptions of the wheat market.

The 1803-1805 crisis was also unusual because of some of the measures adopted by the government to tackle it: holding back part of the tithe mass, exonerating a part of the land rent that tenant farmers had to pay, and the plan to encourage municipal public works. These were innovative regulations and in some cases bold ones, since they broke with secular

56 This was the verdict of the Consejo de Castilla in the following places: Las Rozas, Cebolla, Villanueva de la Sagra, Talavera de la Reina, Santa Cruz de Mudela, Belmonte, San Clemente, Casas Ibáñez, Casasimarro, Villarrobledo. See AHN, Consejos, Sala de Gobierno, file 2375, record 8; file 2364, record 23; file 2412, record 12; file 2410, record 10; file 2127, record 3; file 2345, record 11; file 2127 , record 3 , respectively. 
traditions (the right of owners of rural property to receive the income stipulated in contracts) and led to even heavier criticism of a basic institution of the Ancien Régime, the tithe. In fact, the dispute over agricultural surpluses among monarchy, nobles, local oligarchies and the clergy, at a time when the state's financial needs were rising rapidly, constituted a fundamental aspect of the crisis of the Ancien Régime (Yun 1987, p. 603).

Finally, the 1803-1805 crisis was special because it gave rise to breakups "at the top», propitiated a strong popular uprising, which attained, at least in part, some of its aims, and destabilised the functioning of basic institutions of the Ancien Régime. First, the Church saw once more that the Crown made blatant use of its income or property to deal with extreme situations. In addition, local authorities protected or fomented the ban of extraction of grain from villages and grain mandatory pricing to avoid any worsening of the social crisis and the relapse into popular uprisings, measures that probably did not have the support of all sectors of the oligarchy. What is more, the crisis of 1803-1805 clearly revealed to a significant part of the population of Castile that the political-administrative system was unable to solve its basic economic problems, especially those of supplying basic foodstuff in times of shortage. The experience of these years may explain why, during the Independence War against the French army, so many Spaniards sought solutions outside the old system.

\section{REFERENCES}

Abarca, V.; Bernardos, J. U., Llopis, E., Sebastián, J. A., and Velasco, Á. L. (2015): «El descenso de la mortalidad en la España interior: Albacete y Ciudad Real, 1700-1895». América Latina en la Historia Económica (3), pp. 108-144.

ANEs, G. (1969): Economía e ilustración en la España del siglo XVIII. Barcelona: Ariel.

ANES, G. (1970): Las crisis agraria en la España moderna. Madrid: Taurus.

Bengtsson, T. (2004): «Mortality and Social Class in Four Scanian Parishes, 1766-1865», in T. Bengtsson, C. Campbell, J. Z. Lee, et al. (eds), Life under Pressure. Mortality and Living Standards in Europe and Asia, 1700-1900. Cambridge, MA and London, England: MIT Press, pp. 135-171.

Bernal, A. M. (1979): La lucha por la tierra en la crisis del Antiguo Régimen. Madrid: Taurus.

Bernardos, J. U. (2003a): Ciudad sin puerto. El sistema de abastecimiento del trigo ultramarino hacia Madrid durante el siglo XVIII», in B. Marin and C. Virlouvet (eds), Nourrir les cités de Meditarranée. Antiquité-Temps modernes. Paris: Maisonneuve \& Larose, pp. 801-823.

Bernardos, J. U. (2003b): Trigo castellano y abasto madrileño. Los arrieros y comerciantes de Sangarcía y Etreros durante la Edad Moderna. Valladolid: Junta de Castilla y León.

Campbell, C.; Lee, J. Z., and Bengtsson, T. (2004): "Economic Stress and Mortality», in T. Bengtsson, C. Campbell, J. Z. Lee, et al. (2004), Life under Pressure. Mortality and Living Standards in Europe and Asia, 1700-1900. Cambridge, MA and London, England: MIT Press, pp. 61-84. 
Castro, C. (1987): El pan de Madrid. El abasto de las ciudades españolas del Antiguo Régimen. Madrid: Alianza.

ChesnaIs, J.-C. (1986): La transition démographique. Etapes, formes, implications économiques. Étude de séries temporelles (1720-1984) relatives à 67 pays. Paris: INED, Presses Universitaires de France.

Del Panta, L., and Livi Bacci, M. (1977): Chronologie, intensité et diffusion des crises de mortalité en Italie: 1600-1850. Population, París, pp. 401-446.

Demerson, P. (1969): «La distribución de sopas económicas por la Real Sociedad Matritense en 1803-1804». Boletín de la Real Academia de la Historia CLXIV, pp. 119-137.

Drive, M.; Olsson, M., and Svensson, P. (2011): "Production, Prices and Mortality: Demographic Response to Economic Hardship in Rural Sweden, 1750-1860», European Historical Economic Society, Dublin (September 2-3).

Fernández Hidalgo, M. C., and García Ruipérez, M. (1989): "La crisis agraria de 1802-1806 en la provincia de Toledo a través de los precios del trigo». Revista de Historia Económica Año VII (2), pp. 323-353.

FLinN, M. W. (1989): «The stabilization of mortality in pre-industrial western Europe». The Journal of European Economic History 3, pp. 285-318.

GARCía GARCÍA, C. (1996): La crisis de las haciendas locales. De la reforma administrativa a la reforma fiscal (1743-1845). Valladolid: Junta de Castilla y León.

Garcia Sanz, Á. (1977): Desarrollo y crisis del Antiguo Régimen en Castilla la Vieja. Economía y sociedad en tierras de Segovia, 1500-1814. Madrid: Akal.

Grafe, R. (2012): Distant Tyranny. Markets, Power, and Backwardness in Spain, 1650-1800. Princeton and Oxford: Princeton University Press.

Grupo Complutense de Historia Económica Moderna. (2013): «La mortalidad catastrófica y su papel en el declive de la mortalidad general en las dos Castillas, 1700-1864». XIV Congreso de la SEHA. Sesión Plenaria III. Crisis económicas y crisis alimentarias en el mundo rural: los efectos de los shocks nutricionales a partir de patrones históricos, Badajoz (noviembre 7-9).

Lee, J. Z.; Bengtsson, T., and Campbell, C. (2004): «Mortality and Social Class in Four Scanian Parishes, 1766-1865», in T. Bengtsson, C. Campbell, J. Z. Lee, et al. (eds), Life under Pressure. Mortality and Living Standards in Europe and Asia, 1700-1900. Cambridge, MA and London, England: MIT Press, pp. 85-105.

Llombart, V. (2000): «El pensamiento económico de la Ilustración en España (1730-1812)», in E. Fuentes Quintana (ed.), Economía y economistas españoles. 3. La Ilustración. Barcelona: Galaxia Gutenberg y Círculo de Lectores, pp. 7-89.

Llopis, E. (2014): «España, 1750-2008: crecimiento, cambios y crisis», in J. Gelman, E. Llopis and C. Marichal (eds), Iberoamérica y España antes de las Independencias, 1700-1820: crecimiento, reformas y crisis. México DF: Instituto Mora, pp. 389-445.

LLopis, E., and SотосA, S. (2005a): «Antes, bastante antes: La primera fase de la integración del mercado español del trigo, 1725-1808». Historia Agraria 36, pp. 225-262.

LLOPIS, E., and Sotoca, S. (2005b): «La integración del mercado español del trigo en los siglos XVIII Y XIX: un proceso precoz, prolongado y agitado». VIII Congreso de la Asociación Española de Historia Económica. Sesión B. 10. Renta de la tierra, comercio, mercados y consumo de productos agrarios, siglos XIII-XIX, Santiago de Compostela (septiembre 13-16).

López García, J. M. (1990): La transición del feudalismo al capitalismo en un señorío monástico castellano. El Abadengo de la Santa Espina (1147-1835). Valladolid: Junta de Castilla y León.

Magalhaes Godinho, V. (1955): Prix et Monnaies au Portugal, 1750-1850. Paris: Librairie Armand Colin. 
Malanima, P. (1976): «Aspetti di mercato e prezzi del grano e della segale a Pisa dal 1548 al 1818», in M. Mirri (ed.), Ricerche di storia moderna I, Pisa, 288-327.

MARICHAL, C. (2007): Bankruptcy of Empire. Mexican Silver and the Wars between Spain, Britain and France, 1760-1810. Cambridge: Cambridge University Press.

Moreno Lázaro, J. (2002): «Fomentó el capitalismo agrario la desigualdad? Salarios y niveles de vida en Castilla la Vieja, 1751-1861», in J. M. Martínez Carrión (ed.), El nivel de vida en la España rural, siglos XVIII-XX. Alicante: Universidad de Alicante, pp. 75-112.

O'Rourke, K. H. (2006): «The Worldwide Economic Impact of the French Revolutionary and Napoleonic Wars, 1793-1815». Journal of Global History 1, pp. 123-149.

Pérez Moreda, V. (1980): Las crisis de mortalidad en la España interior (siglos XVI-XIX). Madrid: Siglo XXI.

Pérez Moreda, V. (1984): «Crisis demográficas y crisis agrarias: paludismo y agricultura en España a fines del siglo XVIII», in Casa de Velázquez/Universidad Complutense (eds.), Congreso de Historia Rural. Siglos XV al XIX. Madrid: Universidad Complutense de Madrid, pp. 333-354.

Peset, J. L., and Carvalho, J. A. (1972): «Hambre y enfermedad en Salamanca. Estudio de la repercusión de la "crisis de subsistencias" de 1803-1805 en Salamanca». Asclepio XXIV, pp. 225-266.

Post, J. D. (1976): "Famine, Mortality and Epidemic Disease in the Process of Modernization». Economic History Review XXIX (1), pp. 14-37.

Prados De La Escosura, L. (1993): "La pérdida del Imperio y sus consecuencias económicas», in L. Prados de la Escosura and S. Amaral (eds), La independencia americana: consecuencias económicas. Madrid: Alianza Universidad, pp. 253-329.

ReHER, D. S. (1980): «La crisis de 1804 y sus repercusiones demográficas: Cuenca (1775-1825)». Moneda y Crédito (154), pp. 35-72.

Rodríguez LóPEz-Brea, C. (1995): «La crisis del Antiguo Régimen en el arzobispado de Toledo. El impago de diezmos (1800-1820)», in D. J. María and P. L. Manuel (eds), Antiguo Régimen y liberalismo. Homenaje a Miguel Artola. 2. Economía y Sociedad. Madrid: Alianza Editorial-Universidad Autónoma de Madrid, pp. 285-293.

Ruiz Torres, P. (2007): Historia de España. Volumen V. Reformismo e Ilustración. Barcelona: Crítica y Marcial Pons.

Sanchez Salazar, F. (1988): Extensión de cultivos en España en el siglo XVIII. Madrid: Ministerio de Agricultura, Pesca y Alimentación-Siglo XXI.

SANTos, R. (2012): «Food Dearth and Demographic Behaviour in Southern Portugal. The Region of Évora, 17th-19th Centuries». Workshop Harvest Fluctuations and Food Shortages in European Rural Societies, Lisbon, FCSH-UNL (November 19).

Yun, B. (1987): Sobre la transición al capitalismo en Castilla. Economía y Sociedad en Tierra de Campos (1500-1830). Valladolid: Junta de Castilla y León. 